\title{
IODIDE IONS SORPTION ON POLYMER AV-17(Cl) AND SORBENT AV-17(Bi)
}

\author{
Vasile Gutsanu \\ Moldova State University, 60, A. Mateevici str., Chisinau MD-2009, Republic of Moldova \\ e-mail: gutsanu@gmail.com
}

\begin{abstract}
The iodide ions sorption from solutions of $\mathrm{KI}$ and $\mathrm{KI}$ in excess of $\mathrm{KCl}$ has been investigated. The strongly basic anion exchangers $\mathrm{AV}-17$ in $\mathrm{Cl}^{-}$form and Varion $\mathrm{AD}$ in $\mathrm{NO}_{3}^{-}$form was used as sorbents. Also $\mathrm{AV}-17$ polymer modified with $\mathrm{Bi}(\mathrm{III})$-containing compounds were used. The sorption was performed in static and dynamic conditions. Isotherms are approximated with BET sorption model. The sorption value of iodide ions in the KI solutions with $\mathrm{KCl}$ in excess is quite high. It was established that sorption of iodide ions in the form of polyiodide occurs both as a result of anion exchange and as a result of chemisorption.
\end{abstract}

Keywords: strongly basic anion exchanger, iodide ions, sorption, Bi(III) compounds.

\section{Introduction}

It is well known that iodine is a very important element for normal function of the human organism. In many countries, including Republic of Moldova, the population suffers from iodine deficiencies in the nutrients. Therefore the obtaining of elemental iodine is an actual problem. There are two main sources of iodine: (i) the marine flora and fauna and (ii) the water of the oil wells. The iodine content in water from getting oil drilling is relatively high, ranging between $10-60 \mathrm{mg} / \mathrm{L}[1]$.

Basically there are two following methods of extraction of iodine from aqueous solutions: (i) extraction and (ii) sorption methods. Adsorption methods are based on the use of anion-exchangers. The process of iodide ions interaction with strongly basic anion exchangers was investigated in a number of scientific papers [1-5]. The authors have been mentioned that sorption of iodide ions from different solutions by polymers containing strongly basic functional groups is over equivalent. Although sorption studies of iodide ions by strongly basic anion exchanger is carried out for a long time, sorbate-sorbent interaction mechanism is not yet fully elucidated. It is found that the sorption of iodide ions occurs as a result of the formation of polyiodide ions in polymer phase. This process is performed by the anion exchange and chemical sorbate-sorbent interactions.

Researches of iodide ions adsorption on anion exchangers modified with metal compounds have not yet been done. It is necessary to perform such research not only to recover iodide ions from solutions, but also in order to elucidate the mechanism of sorbate-sorbent interaction. It should also be noted that the polymers containing polyiodide ions can serve as sorbents for the removal of reductants from gaseous phase such as phosphine [6], hydrazine [7] and others.

\section{Experimental}

The commercial strongly basic anion exchangers AV-17 and Varion-AD have been used. The exchangers are gel-type cross-linked polystyrene-divinylbenzene copolymers. The AV-17 have $-\mathrm{N}^{+}\left(\mathrm{CH}_{3}\right)_{3}$ and Varion-AD $-\mathrm{N}^{+}\left(\mathrm{CH}_{3}\right)_{3}$ and -OH functional groups. Their full anion-exchange capacity is $3.5-4.0 \mathrm{meq} / \mathrm{g}$ [10]. The exchanger AV-17 was in Clform, while Varion- $\mathrm{AD}$ was in $\mathrm{NO}_{3}^{-}$form. Polymer $\mathrm{AV}-17$ modified with $\mathrm{Bi}(\mathrm{III})$ compounds also was investigated. The process of obtaining of the sorbent $\mathrm{AV}-17(\mathrm{Bi})$ takes place according to the method described elsewhere [11]. The AV$17(\mathrm{Cl})$ polymer dried sample $(5 \mathrm{~g})$ have been contacted with $0.014 \mathrm{M} \mathrm{Bi}(\mathrm{OH})_{2} \mathrm{NO}_{3}$ solution $(0.5 \mathrm{~L})$ at a temperature of $60 \pm 1^{\circ} \mathrm{C}$ for $5 \mathrm{~h}$. The $\mathrm{pH}$ value of $\mathrm{Bi}(\mathrm{OH})_{2} \mathrm{NO}_{3}$ solution was about 0.2 . After $5 \mathrm{~h}$ of contacting time the polymer sample was separated by filtration, washed with distilled water and dried in air. The polymer modified with $\mathrm{Bi}(\mathrm{III})$ compounds contains crystalline $\mathrm{BiOCl}$ and amorphous $\mathrm{BiOOH}[9]$. The Bi content (25.3 $\mathrm{mg} \mathrm{Bi} / \mathrm{g}$ ) in the prepared sorbent AV-17(Bi) was determined photocolorimetrically [12] after desorption with $\mathrm{HNO}_{3}$ solution.

Sorption of the iodide ions occurred in solutions containing (i) $\mathrm{KI}$ and (ii) mixture of $\mathrm{KI}$ and $\mathrm{KCl}$. The investigation was carried out in static and dynamic conditions. In the static conditions the polymer samples of $0.2 \mathrm{~g}$ were contacted with $50 \mathrm{~mL}$ of solution. When was necessary, the $\mathrm{pH}$ value of solution was adjusted using solution of $\mathrm{H}_{2} \mathrm{SO}_{4}$ or $\mathrm{NaOH}$.

The sorption value was calculated with the Eq.(1):

$S=\frac{\left(C_{0}-C_{e}\right) V}{m}$,

where, $S$ is the sorption value, $\mathrm{mmol} \mathrm{I} / \mathrm{g} ; C_{0}$ and $C_{e}$ are the initial and, respectively, the equilibrium concentrations of $\mathrm{I}^{-}(\mathrm{mg} \mathrm{I} / \mathrm{mL}), V$ is the solution volume in contact with polymer sample, $\mathrm{mL} ; m$ is the mass of polymer sample, $\mathrm{g}$. 
The investigation of iodide ions sorption in the dynamic conditions was carried out using glass column with diameter of $10.7 \mathrm{~mm}$. Solutions with $\mathrm{pH} 5.0$ - 5.2 containing $0.64 \mathrm{mg} \mathrm{I} / \mathrm{mL}$ have been passed through the column, containing $2 \mathrm{~g}$ of dried polymer, with different flow.

The parameters of sorption process have been calculated from the breakthrough curves: (i) dynamic sorption capacity (DSC, $\mathrm{mg} \mathrm{I}^{-} / \mathrm{g}$ ) corresponds to sorption value until the appearance of the iodide ions into effluents; (ii) total dynamic sorption capacity (TDSC, $\left.\mathrm{mg} \mathrm{I}^{\mathrm{F}} / \mathrm{g}\right)$ - sorption value at the sorbent saturation.

The relative rate of sorption ( $W, \%)$ was calculated according to Eq.(2):

$W, \%=\frac{D S C}{T D S C} \cdot 100 \%$

\section{Results and discussion}

\section{Iodide ions sorption by $\mathrm{AV}-17(\mathrm{Cl})$ in the static conditions}

The results showed that at temperature of $19.5^{\circ} \mathrm{C}$ the equilibrium sorption of iodide ions (in solutions containing $0.25 \mathrm{mg} \mathrm{KI}-/ \mathrm{mL})$ is reached at 10 minutes of the contact with the polymer AV-17(Cl). It was also found that the sorption practically does not depend on the solution $\mathrm{pH}$ value in the range of 3-10.

Theoretically, iodide ions sorption on strongly basic anion exchanger should be a reversible process according to the Eq.(3):

$\mathrm{R}_{4} \mathrm{NCl}+\mathrm{I}^{-} \leftrightarrow \mathrm{R}_{4} \mathrm{NI}+\mathrm{Cl}^{-}$

But sorption isotherm obtained at $16.5^{\circ} \mathrm{C}$, shows that iodide ions retention on $\mathrm{AV}-17(\mathrm{Cl})$ from $\mathrm{KI}$ solution is not determined by the anion exchange process only (see Figure 1). The shape of sorption isotherm is similar to the BET isotherm. This indicates that in the polymer phase take place processes of condensation of iodide ions as a result of forming of polyiodide ions $\mathrm{I}_{2} \mathrm{I}_{2}$ ). This indicates that in the system containing polymer and KI solution, the redox processes take place, involving atmospheric oxygen. Polyiodide ions formation in the polymer phase is confirmed by the fact that the sorption value is much higher than the theoretical exchange capacity of the polymer.

The isotherm parameters using BET adsorption model were calculated by Eq. (4):

$S=\frac{S_{\infty} B\left(C / C_{S}\right)}{\left(1-C / C_{S}\right)\left[1+(B-1) C / C_{S}\right]}$,

where, $S$ is sorption value, $\mathrm{mmol} \mathrm{I}^{-} / \mathrm{g} ; S_{\infty}$ is first layer capacity, $\mathrm{mmol} \mathrm{I} / \mathrm{g} ; B$ is a constant, $C$ - equilibrium $\mathrm{I}^{-}$concentration, $\mathrm{mmol} \mathrm{I} / \mathrm{L} ; C_{s}-$ pseudo saturated solution, mmol I/2/L (see Figure 1).

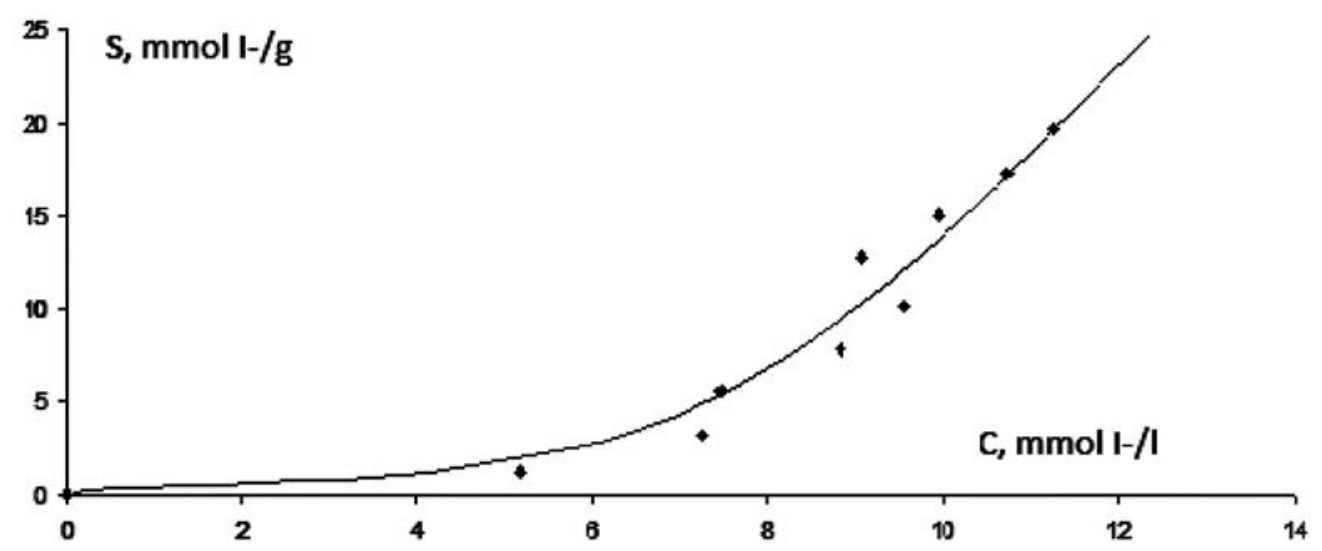

Figure 1. The isotherm of iodide ions sorption from KI solutions on AV-17(Cl).

It is known that BET isotherm describes adsorption of gases. But it can also be used to describe the sorption from solutions when in the sorbent phase the sorbate forms polymeric compounds [8]. Calculation of isotherm constants has been made using the linear form of the BET isotherm (Eq. 5):

$\frac{C / C_{S}}{S \cdot\left(1-C / C_{S}\right)}=\left(\frac{1}{S_{\infty} B}\right)+\left(\frac{(B-1) \cdot C / C_{S}}{S_{\infty} B}\right)$. 


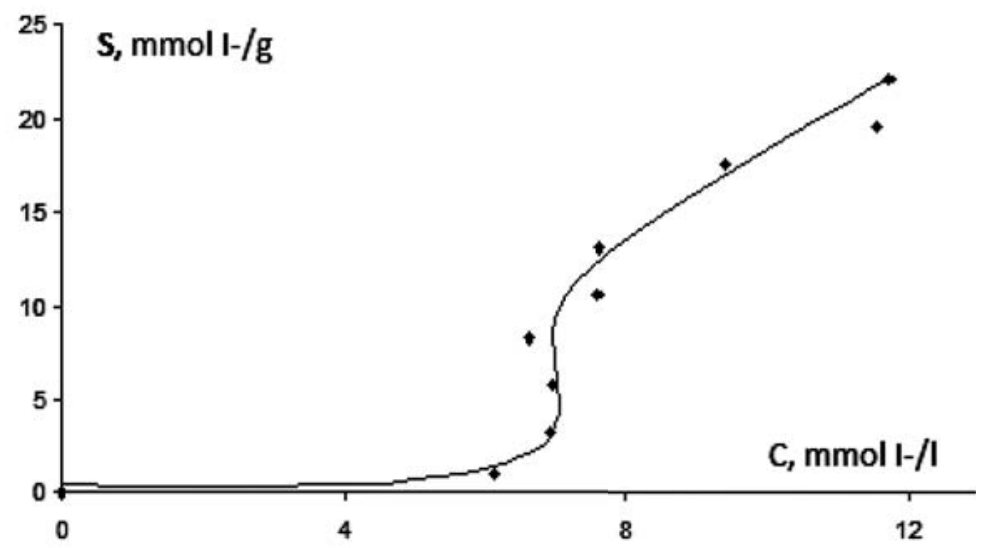

Figure 2. The isotherm of iodide ions sorption on $\mathrm{AV}-17(\mathrm{Cl})$ from solutions containing $\mathrm{KI}$ and $\mathrm{KCl}$.

The linear form of the experimentally obtained isotherm (Figure 1) with $\mathrm{C}_{\mathrm{s}}=13.4 \mathrm{mmol} \mathrm{I} / \mathrm{L}$, is shown in Figure 3 , and the constants values in the Table 1 .

As shown in Figure 1, the forming of the polyiodide ions in the polymer phase begins at concentrations higher than $7 \mathrm{mmol} \mathrm{I} / \mathrm{L}$. It would seem that sorption occurs in outcome (Eq. (6)), i.e. in the result of the anion exchange: $\mathrm{R}_{4} \mathrm{NI}+\mathrm{nI}_{2} \leftrightarrow \mathrm{R}_{4} \mathrm{NI}\left(\mathrm{I}_{2}\right) \mathrm{n}$.

But the results of iodide ions sorption from solutions of $\mathrm{KI}$ with increased concentrations of $\mathrm{KCl}$ demonstrated that it is not so. The sorption isotherm of iodide ions from the $\mathrm{KI}$ solution containing $0.1 \mathrm{~mol} \mathrm{KCl} / \mathrm{L}$ on polymer $\mathrm{AV}$ $17(\mathrm{Cl})\left(\right.$ at $\left.16.5^{\circ} \mathrm{C}\right)$ is shown in Figure 2. The shape of this isotherm is similar to the shape of the sorption isotherm from $\mathrm{KI}$ solution in the absence of $\mathrm{KCl}$ (Figure 1). The linear form of the isotherm calculated using the $\mathrm{BET}$ model with $\mathrm{C}_{\mathrm{s}}=$ $12.8 \mathrm{mmol} \mathrm{I} / \mathrm{L}$, is shown in Figure 3, and the constants values in the Table 1. It is possible that in the polymer phase takes place formation of $\mathrm{I}_{2} \mathrm{Cl}^{-}$ions and others [1]. According to [1], sorption of the iodine containing ions on the AV-17-8 increases in the following order: $\mathrm{I}^{-}<\mathrm{I}_{3}^{-}<\mathrm{I}_{2} \mathrm{Cl}^{-}$.

The $\mathrm{S}_{\infty}$ value of iodine ions sorption from $\mathrm{KI}$ solution containing $\mathrm{KCl}$ is much lower in comparison with solution without $\mathrm{KCl}$ (Table 1). This means that in solutions with low concentrations of $\mathrm{KI}(\mathrm{C}<7 \mathrm{mmol} \mathrm{KI} / \mathrm{L})$, I- ions are in competitions with the $\mathrm{Cl}^{-}$ions. Given the much higher concentration of $\mathrm{KCl}$ than $\mathrm{KI}$, iodide ions sorption from solutions containing $\mathrm{KCl}$ should be much lower than from solutions without $\mathrm{KCl}$, if sorption would be determined by anion exchange. But the results show that sorption of iodide ions from solutions containing excess of $\mathrm{KCl}$ is no lower than from solutions without $\mathrm{KCl}$. These results suggest that a part of iodide ions and polyiodide is retained by $\mathrm{AV}-17(\mathrm{Cl})$ due to the anion exchange process and another as a result of a chemical interaction with polymer matrix.

Table 1

Isotherms constants of iodine ions sorption on $\mathrm{AV}-17(\mathrm{Cl})$ and $\mathrm{AV}-17(\mathrm{Bi})$.

\begin{tabular}{lccccc}
\hline \multicolumn{1}{r}{ Sorbent } & Solution & $\begin{array}{c}\text { Temperature, } \\
{ }^{\circ} \mathrm{C}\end{array}$ & $\mathrm{pH}_{\text {eq }}$ & $\begin{array}{c}S_{\infty}, \\
\mathrm{mmol} / \mathrm{g}\end{array}$ & $\begin{array}{c}B, \\
\mathrm{~g} / \mathrm{mmol}\end{array}$ \\
\hline $\mathrm{AV}-17(\mathrm{Cl})$ & $\mathrm{KI}$ & 16.5 & $4.85-5.65$ & 0.74 & 48.5 \\
$\mathrm{AV}-17(\mathrm{Cl})$ & $\mathrm{KI}+\mathrm{KCl}$ & 16.0 & $4.66-5.95$ & 0.46 & 33.8 \\
\hline
\end{tabular}

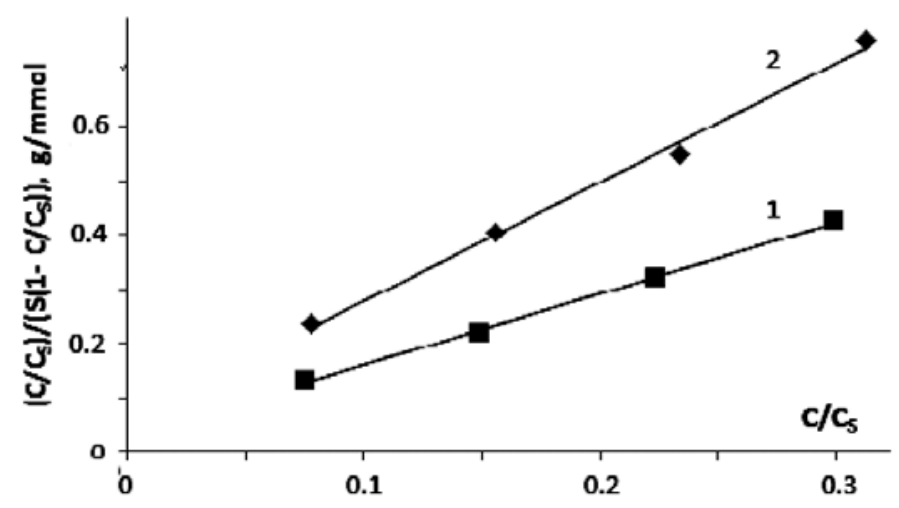

Figure 3. The linear BET isotherms of iodide ions sorption on AV-17(CI) from KI solutions (1) and solutions containing $\mathrm{KI}$ and $\mathrm{KCl}(2)$. 
It is known, that at low concentrations the BET isotherm turns to Langmuir isotherm. Indeed, sorption of iodide ions at $19.5^{\circ} \mathrm{C}$ in solutions with low concentrations of $\mathrm{KI}$ on the polymer Varion- $\mathrm{AD}\left(\mathrm{NO}_{3}^{-}\right)$(strongly basic anion exchanger, analogue AV-17) is described by the Langmuir sorption model (Figure 4) according to Eq.(7):

$S=\frac{S_{\infty} K C}{(1+K C)}$

where, $K$ is a constant $(\mathrm{L} / \mathrm{mmol}), C$ - equilibrium concentration of iodide ions $(\mathrm{mmol} / \mathrm{L})$.

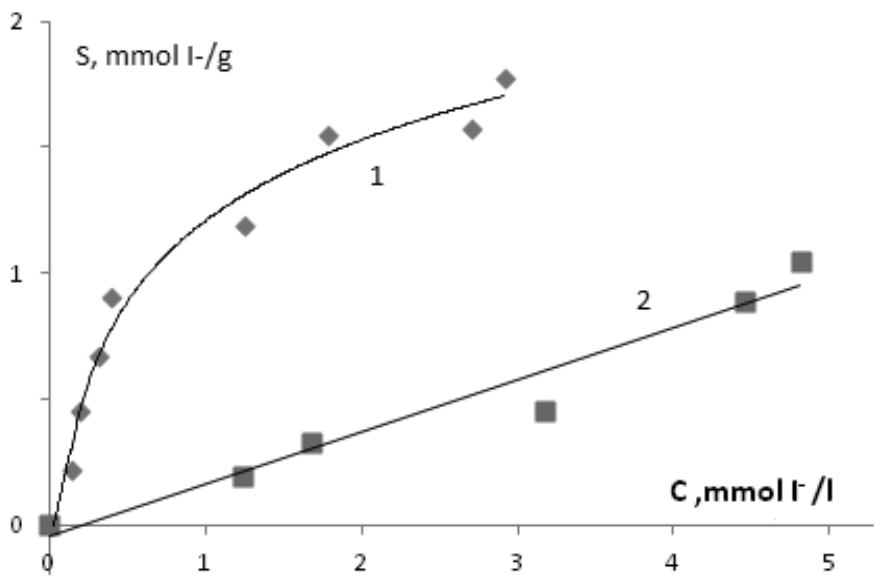

Figure 4. The isotherms of iodide ions sorption by Varion- $\mathrm{AD}\left(\mathrm{NO}_{3}\right)$ from KI solutions (1) and solutions containing $\mathrm{KI}$ and $\mathrm{KCl}(2)$.

Using linear form of the Langmuir isotherm (Figure 5), performed according to the Eq.(8), the constants $S_{\infty}$ and $K$ were calculated.

$\frac{C}{S}=\frac{1}{\left(S_{\infty} K\right)}+\frac{C}{S_{\infty}}$

The following values of the constants: $\mathrm{S}_{\infty}=1.84 \mathrm{mmol} \mathrm{I} / \mathrm{g}$ and $\mathrm{K}=2.134 \mathrm{~L} / \mathrm{mmol}$ were obtained. The sorption isotherm of iodide ions from $0.1 \mathrm{M} \mathrm{KCl}$ solutions on Varion-AD, obtained at $19.5^{\circ} \mathrm{C}$, is approximately described by Henry sorption model (Figure 4) with $\mathrm{K}=0.206 \mathrm{~L} / \mathrm{g}$.

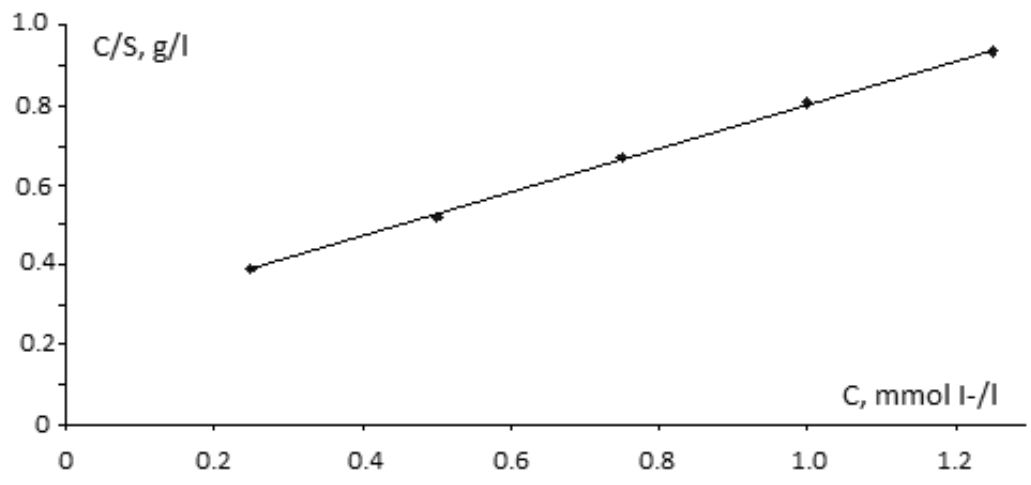

Figure 5. The linear Langmuir isotherm of iodide ions sorption from KI solutions on Varion-AD( $\left.\mathrm{NO}_{3}\right)$.

\section{Iodide ions sorption on $\mathrm{AV}-17(\mathrm{Bi})$ in the static conditions}

As shown in Figure 6, the iodide ions sorption isotherm from KI solutions by sorbent AV-17(Bi), obtained at $12.5^{\circ} \mathrm{C}$, also can be described by the BET sorption model. The isotherms of iodide ions sorption on AV-17(Bi) sorbent from solutions containing $\mathrm{KI}$ and $\mathrm{KCl}$, obtained at $16^{\circ} \mathrm{C}$ and $60^{\circ} \mathrm{C}$ (Figure 7), also correspond to the BET adsorption model. From linear BET isotherms (Figure 8) considering $\mathrm{C}_{\mathrm{s}}=23.2 \mathrm{mmol} \mathrm{I} / \mathrm{L}$ (sorption from KI solutions), $\mathrm{C}_{\mathrm{s}}=21$ 
$\mathrm{mmol} \mathrm{I} / \mathrm{L}$ (sorption at $16^{\circ} \mathrm{C}$ from solutions containing $\mathrm{KI}$ and $\mathrm{KCl}$ ) and $\mathrm{C}_{\mathrm{s}}=17 \mathrm{mmol} \mathrm{I} / \mathrm{L}$ (sorption at $60^{\circ} \mathrm{C}$ from solutions containing $\mathrm{KI}$ and $\mathrm{KCl}$ ) were calculated constants shown in the Table 2.

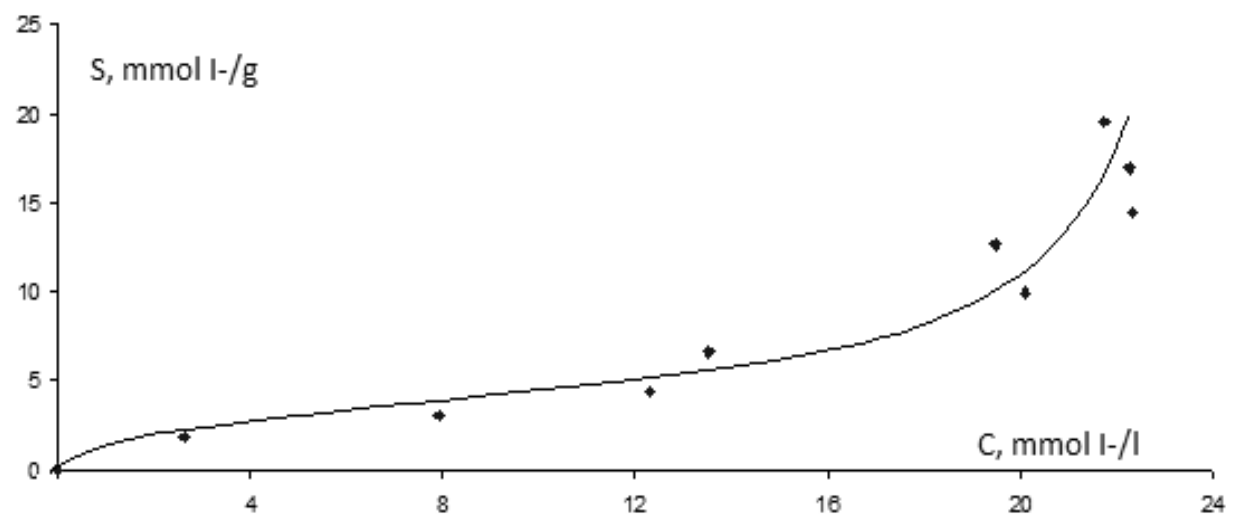

Figure 6. The isotherm of iodide ions sorption from KI solutions on AV-17(Bi).

Table 2

Isotherms constants of iodine ions sorption on $\mathrm{AV}-17(\mathrm{Cl})$ and $\mathrm{AV}-17(\mathrm{Bi})$.

\begin{tabular}{lccccc}
\hline \multicolumn{1}{c}{ Sorbent } & Solution & $\begin{array}{c}\text { Temperature, } \\
{ }^{\circ} \mathrm{C}\end{array}$ & $\mathrm{pH}_{e q}$ & $\begin{array}{c}S_{\infty}, \\
\mathrm{mmol} / \mathrm{g}\end{array}$ & $\begin{array}{c}B, \\
\mathrm{~g} / \mathrm{mmol}\end{array}$ \\
\hline $\mathrm{AV}-17(\mathrm{Bi})$ & $\mathrm{KI}$ & 12.5 & $5.0-6.15$ & 2.23 & 15.2 \\
$\mathrm{AV}-17(\mathrm{Bi})$ & $\mathrm{KI}+\mathrm{KCl}$ & 16.0 & $5.1-6.2$ & 2.03 & 10.5 \\
$\mathrm{AV}-17(\mathrm{Bi})$ & $\mathrm{KI}+\mathrm{KCl}$ & 60.0 & $4.54-6.1$ & 1.87 & 7.8 \\
\hline
\end{tabular}

From the Figures 6 and 7, and $\mathrm{S}_{\infty}$ values (Table 2) we can see that the monolayer sorption capacity of the sorbent $\mathrm{AV}-17(\mathrm{Bi})$ is much higher than of the polymer $\mathrm{AV}-17(\mathrm{Cl})$. It means that the compounds of $\mathrm{Bi}(\mathrm{III})$ in the polymer phase also are involved in the processes of iodide ions sorption. It is important to remark that the sorption of iodine ions slightly depends on the presence of $\mathrm{KCl}$ excess in the $\mathrm{KI}$ solution and on temperature. If to compare the data from the Figures 1 and 2, and Figures 6 and 7, we can see that the value of iodide ions sorption on AV-17(Cl) and AV-17(Bi) samples is almost the same.

It would seem that in the similar conditions maximal iodide ions sorption on $\mathrm{AV}-17(\mathrm{Bi})$ must be larger than on the $\mathrm{AV}-17(\mathrm{Cl})$ because in the first sorbent there are $\mathrm{R}_{4} \mathrm{NNO}_{3}$ and $\mathrm{Bi}(\mathrm{III})$-containing sorption centers and in the $\mathrm{AV}-17(\mathrm{Cl})$ there are only $\mathrm{R}_{4} \mathrm{NCl}$ centers. It can be explained by the fact that a part of $\mathrm{Bi}(\mathrm{III})$ compounds are situated on $\mathrm{R}_{4} \mathrm{NNO}_{3}$ groups and block the iodine ions access to them [9].

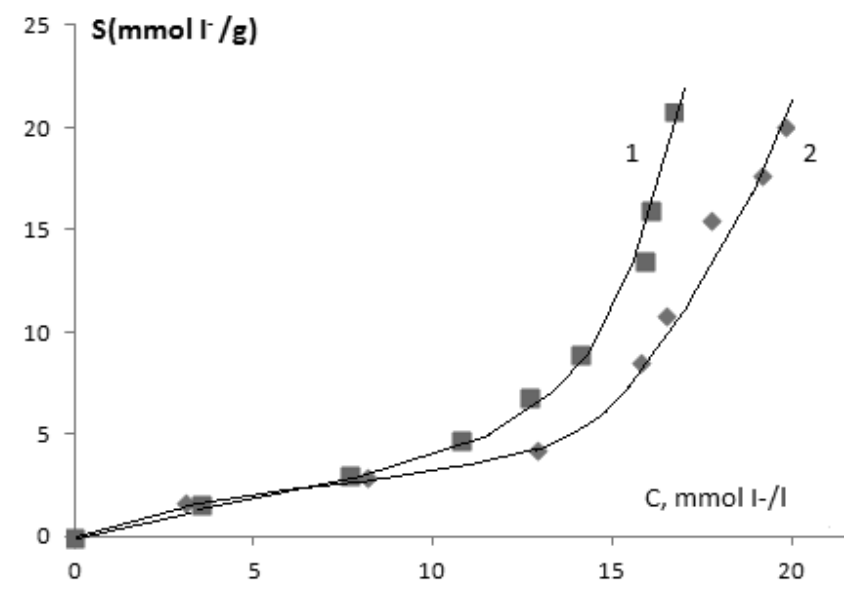

Figure 7. The isotherms of iodide ions sorption on $\mathrm{AV}-17(\mathrm{Bi})$ at $60^{\circ} \mathrm{C}(1)$ and $16^{\circ} \mathrm{C} \mathrm{(2)} \mathrm{from} \mathrm{solutions} \mathrm{containing} \mathrm{KI}$ and $\mathrm{KCl}$. 


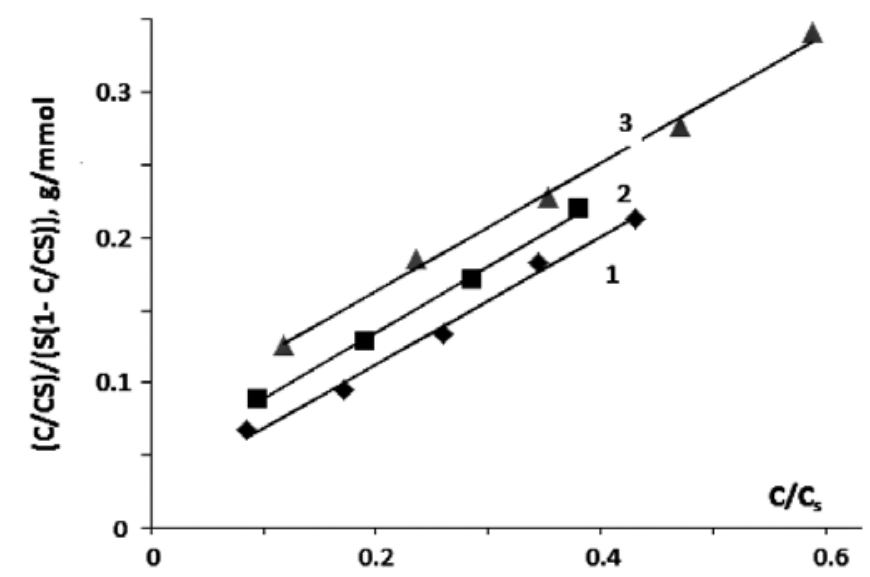

Figure 8. The linear BET isotherms of iodide ions sorption on AV-17(Bi) from KI solutions (1), from solutions containing $\mathrm{KI}$ and $\mathrm{KCl}$ at $16^{\circ} \mathrm{C} \mathrm{(2)}$ and at $60^{\circ} \mathrm{C} \mathrm{(3).}$

Iodide ions sorption on $A V-17(C l)$ and $A V-17(B i)$ in dynamic conditions

Solution of KI with initial concentration of $\mathrm{C}_{0}=0.635 \mathrm{mg} \mathrm{I} / \mathrm{mL}, \mathrm{pH}_{0}=5.0$ and a temperature of $14^{\circ} \mathrm{C}$ has been passed through the column containing $2 \mathrm{~g}$ of polymer AV-17(Cl) with a flow of $4.46 \mathrm{~mL} / \mathrm{min}$. In the effluents the concentration of $\mathrm{I}^{-}$ions and the value of $\mathrm{pH}$ were measured. From the obtained experimental data the dependencies $\mathrm{C}$ $=\mathrm{f}(\mathrm{V})$ and $\mathrm{pH}=\mathrm{f}(\mathrm{V})$ were performed, where $\mathrm{V}$ is the volume of effluents. These dependencies are shown in Figures 9 and 10 .

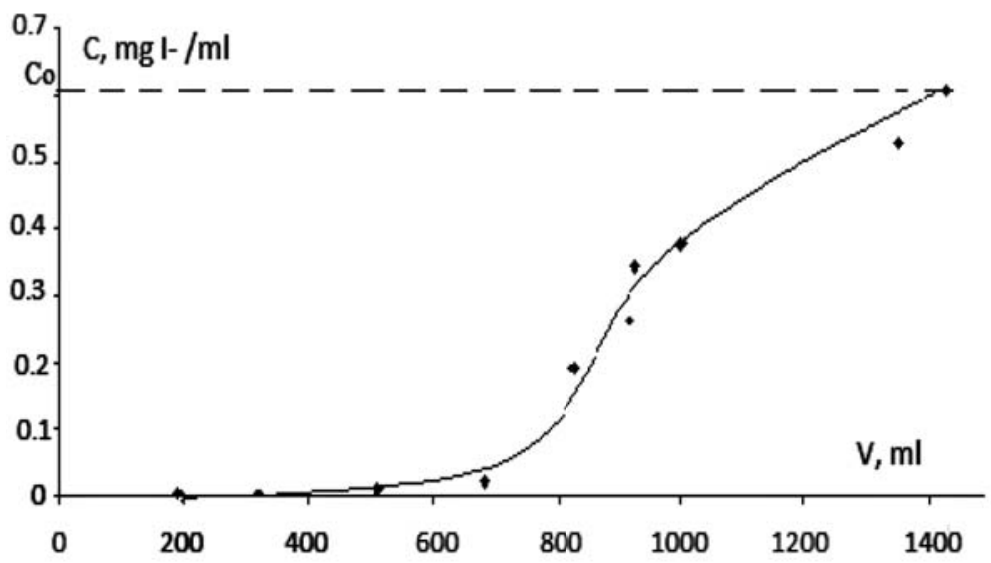

Figure 9. Breakthrough curves for sorption of iodine ions from KI solution on AV-17(Cl).

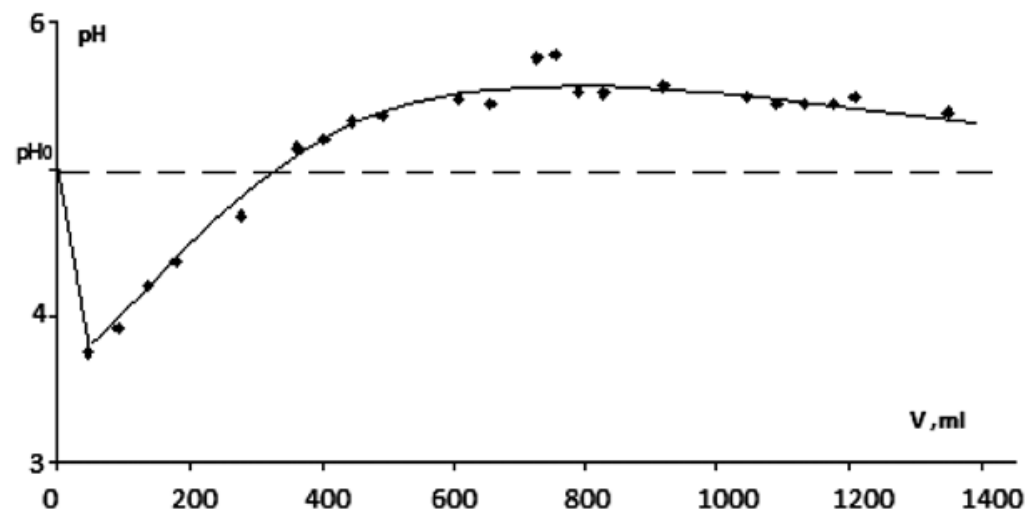

Figure 10. pH value of effluents during of iodide ions sorption on AV-17(CI) from KI solution. 
The dynamic sorption capacity (DSC), the total dynamic sorption capacity (TDSC) and the relative rate of sorption (W) were calculated from Figure 9 and are presented in the Table 3. The values of these parameters are quite high.

Table 3

Data of the iodide ions sorption in dynamic conditions.

\begin{tabular}{rcccccc}
\hline Sorbent & Solution & $\begin{array}{c}t, \\
{ }^{\circ} \mathrm{C}\end{array}$ & $\begin{array}{c}\text { Flow rate, } \\
m L / m i n\end{array}$ & $\begin{array}{c}\text { DSC, } \\
m g I / g\end{array}$ & $\begin{array}{c}\text { TDSC, } \\
m g I / g\end{array}$ & $\begin{array}{c}W, \\
\%\end{array}$ \\
\hline $\mathrm{AV}-17(\mathrm{Cl})$ & $\mathrm{KI}$ & 14 & 4.46 & 212.72 & 314.28 & 67.7 \\
$\mathrm{AV}-17(\mathrm{Cl})$ & $\mathrm{KI}+\mathrm{KCl}$ & 16 & 5.00 & 124.46 & 167.10 & 74.5 \\
\hline
\end{tabular}

In Figure 9 it can be seen that the speed of the sorption of iodide ions is quite high. This confirms the high rate of sorption that has been observed in the static conditions.

Sorption of iodide ions in $0.1 \mathrm{M} \mathrm{KCl}$ solutions on polymer $\mathrm{AV}-17(\mathrm{Cl})$ at the same conditions of concentration of $\mathrm{KI}$, temperature and initial $\mathrm{pH}$, but at the flow rate of $5 \mathrm{~mL} / \mathrm{min}$, is lower than in the absence of $\mathrm{KCl}$ in solution (Figure 11, Table 3). But the relative rate of $\mathrm{I}^{-}$ions sorption from solution containing an excess of $\mathrm{KCl}$ is slightly larger (Table 3 ). Although the affinity of the polymer to the iodide ions is much greater than to chloride ions, these ions $\left(\mathrm{Cl}^{-}\right)$significantly affects I- ions sorption. The $\mathrm{pH}$ value of effluents during of iodide ions sorption on $\mathrm{AV}-17(\mathrm{Cl})$ from $\mathrm{KI}$ and $\mathrm{KCl}$ solution is presented in Figure 12.

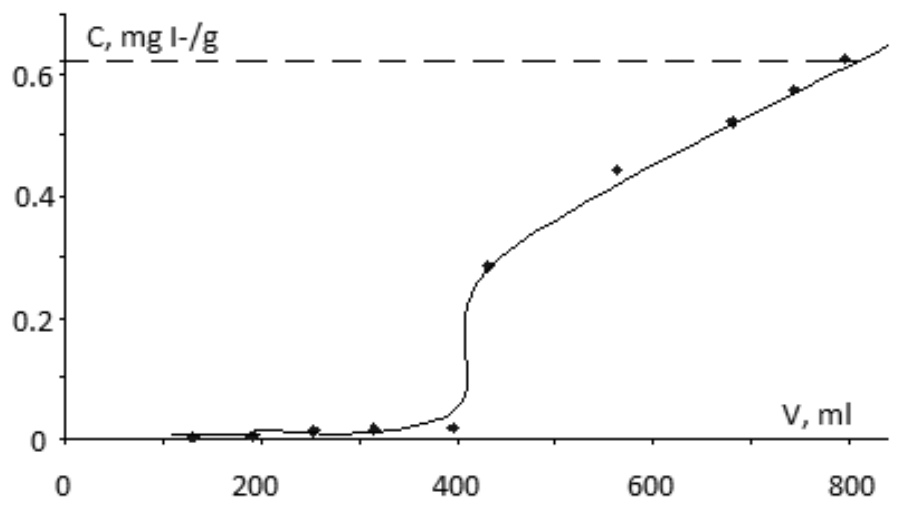

Figure 11. Breakthrough curve for sorption of iodide ions on AV-17(Cl) from KI solution containing $\mathrm{KCl}$.

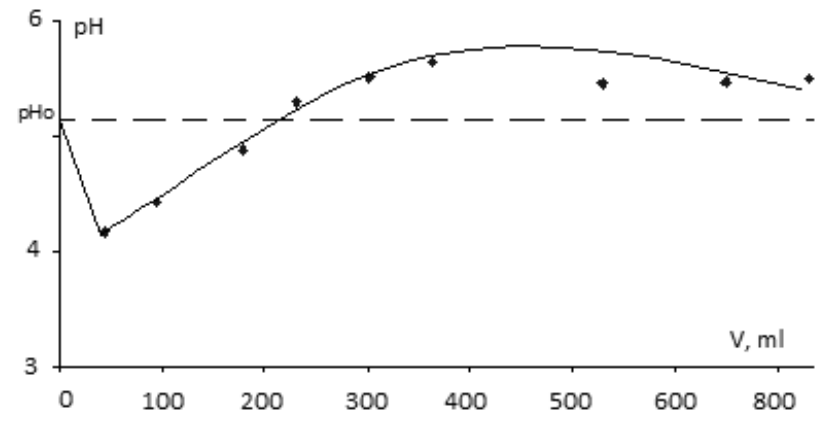

Figure 12. pH value of effluents during of iodide ions sorption on AV-17(Cl) from KI and KCl solution.

The breakthrough curves for sorption of iodide ions from solutions (containing $0.635 \mathrm{mg} \mathrm{I} / \mathrm{mL}$ ) on sorbent AV$17(\mathrm{Bi})$ and $\mathrm{pH}$ of the effluents are similar to those obtained using polymer AV-17(Cl) (Figures 13-16). The values of the sorption parameters are higher than for sorption on $\mathrm{AV}-17(\mathrm{Cl})$ in almost the same conditions. The data in Table 4 show that the iodide ions sorption parameters from solutions containing $\mathrm{KI}$ and $\mathrm{KCl}$ on the sorbent $\mathrm{AV}-17(\mathrm{Bi})$ are lower than those from solutions in absence of $\mathrm{KCl}$. But they are quite high if to take in consideration that concentration of iodide ions is much lower than of the chloride ions. This confirms that the selectivity for iodide ions sorption on $\mathrm{AV}-17(\mathrm{Bi})$ is greater than that on the $\mathrm{AV}-17(\mathrm{Cl})$. 
Decreases of iodide ions sorption from solutions containing excess of $\mathrm{KCl}$ can be explained by the fact that some of the $\mathrm{Cl}^{-}$ions can form $\mathrm{I}_{2} \mathrm{Cl}^{-}$which are retained less by the polymer. With increasing of temperature, concentration of $\mathrm{I}_{2} \mathrm{Cl}^{-}$ions also increases (Figure 7).

Data of the iodide ions sorption in dynamic conditions.

\begin{tabular}{rcccccc}
\hline Sorbent & Solution & $\begin{array}{c}t, \\
{ }^{\circ} \mathrm{C}\end{array}$ & $\begin{array}{c}\text { Flow rate, } \\
m L / m i n\end{array}$ & $\begin{array}{c}\text { DSC, } \\
m g I / g\end{array}$ & $\begin{array}{c}\text { TDSC, } \\
m g I / g\end{array}$ & $\begin{array}{c}W, \\
\%\end{array}$ \\
\hline $\mathrm{AV}-17(\mathrm{Bi})$ & $\mathrm{KI}$ & 16.5 & 4.9 & 263.52 & 377.62 & 69.8 \\
$\mathrm{AV}-17(\mathrm{Bi})$ & $\mathrm{KI}+\mathrm{KCl}$ & 17.5 & 4.6 & 134.00 & 229.15 & 58.5 \\
\hline
\end{tabular}

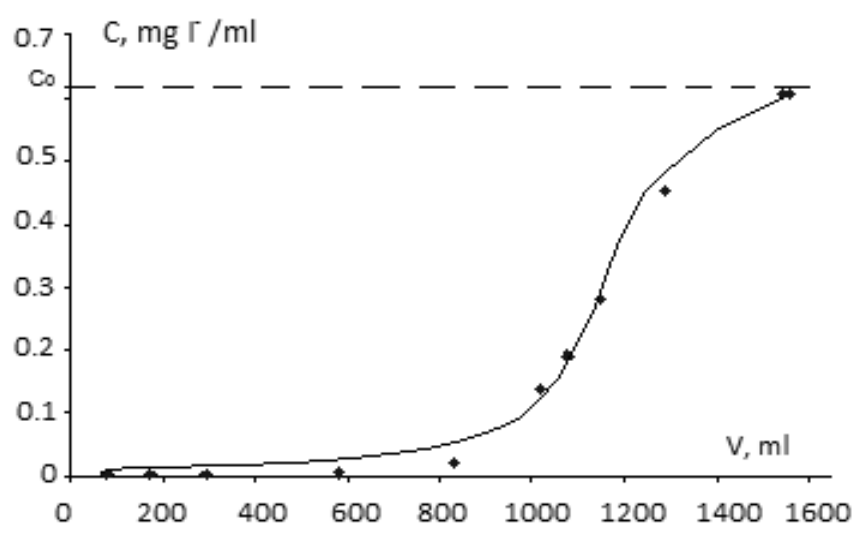

Figure 13. Breakthrough curve for sorption of iodide ions from KI solution on AV-17(Bi).

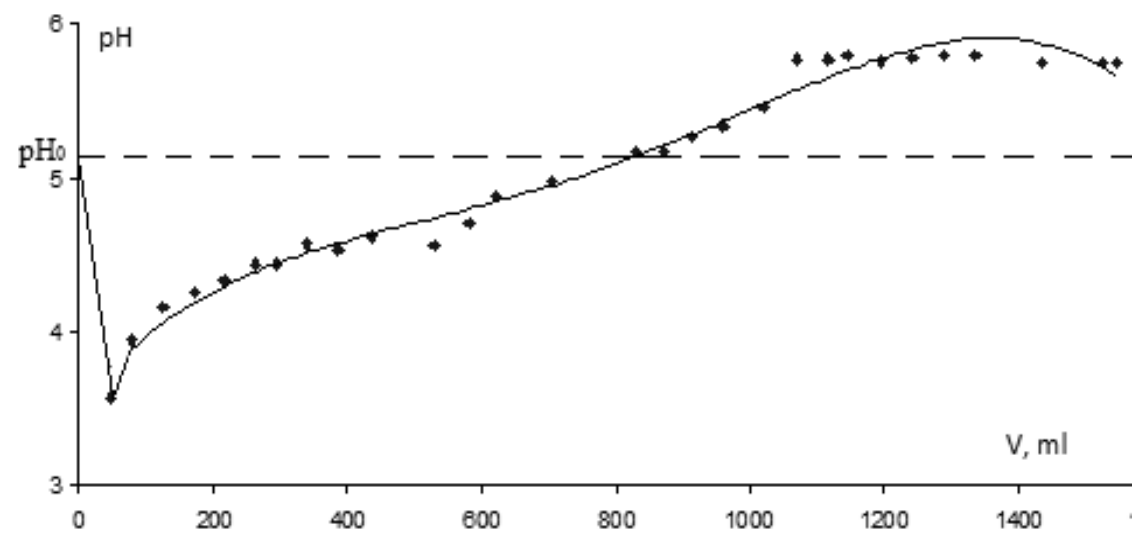

Figure 14. pH value of effluents during of iodide ions sorption on AV-17(Bi) from KI.

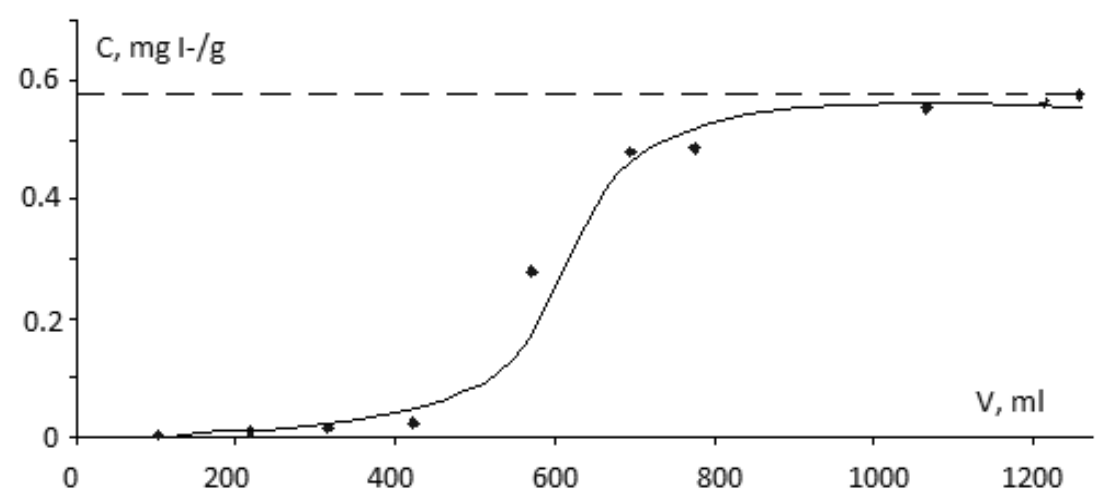

Figure 15. Breakthrough curve for sorption of iodide ions on AV-17(Bi) from solution containing $\mathrm{KI}$ and $\mathrm{KCl}$. 
Comparing the curves from Figures 10, 12, 14 and 16, it was established that in case of absorption from KI solutions and solutions containing $\mathrm{KI}$ and $\mathrm{KCl}$, the variation of $\mathrm{pH}$ value in the effluents volume is almost the same for AV-17(Bi) or AB-17(Cl) samples.

Probably, at the beginning of the process, the polymer retains $\mathrm{OH}^{-}$ions from solution, thus decreasing $\mathrm{pH}$ of the effluent. When promoting sorption layer of iodide ions along the column, $\mathrm{OH}^{-}$ions are displaced in the effluents, increasing its $\mathrm{pH}$. This can be explained by the increase of $\mathrm{pH}$ value in the effluents, which becomes higher than the initial $\mathrm{pH}$ of the solution.

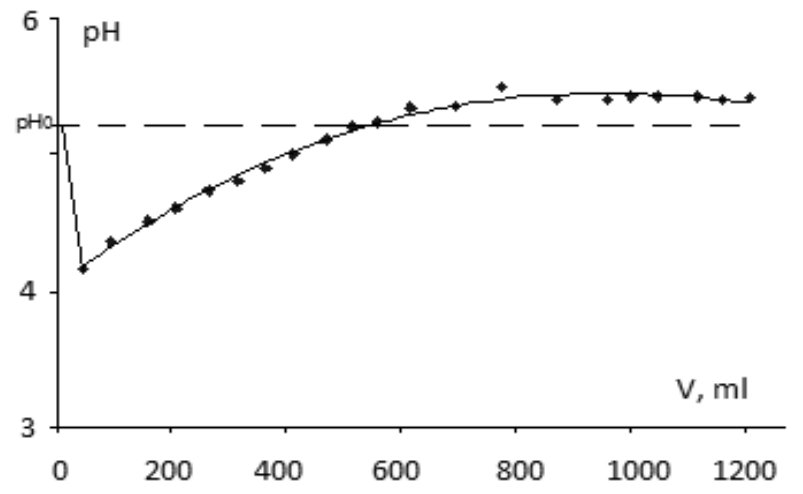

Figure 16. pH value of effluents during of iodide ions sorption on $\mathrm{AV}-17(\mathrm{Bi})$ from $\mathrm{KI}$ and $\mathrm{KCl}$.

Note: Additional qualitative experiments showed that sorbent AV-17(Bi) is able to retain compounds of iodine (and bromine) from Valeni drilling waters.

\section{Conclusions}

Sorption of the iodide ions from solutions by strongly basic anion exchanger AV-17(Cl) and the AV-17(Bi) is a complex process. In the sorbent phase the polyiodide ions are formed. Polyiodide ions are retained by the sorbents in the result of anion exchange and chemisorption. The iodide ions sorption isotherms, obtained from KI and KI containing excess of $\mathrm{KCl}$, can be described by BET sorption model. The iodide ions sorption, both in static and dynamic conditions, is super equivalent. The sorption selectivity of $\mathrm{AV}-17(\mathrm{Bi})$ in dynamic conditions is greater than that of $\mathrm{AV}-17(\mathrm{Cl})$.

\section{Acknowledgments}

The author thanks to V. Lupan for his help in performing of some experiments.

\section{References}

1. Stroeva, E.V. Physico-chemical bases of extracting iodine from solutions of highly mineralized Orenburg gas condensate. Ph.D. thesis, Mendeleev MCT University, Moscow, Russian Federation, 2004. (in Russian).

2. Myagkoy, O.N.; Krasova, K.N.; Serdiucova, M.I.; Meleshko, B.P. Theory and practice of the sorption processes. Voronezh State University: Voronezh, 1974, 9, pp. 86-91 (in Russian).

3. Myagkoy, O.N.; Serdiucova, M.I. Theory and practice of the sorption processes. Voronezh State University: Voronezh. 1977, 12, pp. 67-73 (in Russian).

4. Myagkoy, O.N.; Serdiucova, M.I.; Seryacenko, L.A. Theory and practice of the sorption processes. Voronezh State University: Voronezh, 1981, 16, pp. 36-41(in Russian).

5. Serdiucova, M.I. Theory and practice of the sorption processes. Voronezh State University: Voronezh, 1984, 19, pp. 87-91 (in Russian).

6. Vulih, A.I.; Dubinina, E.G. Redox macromolecular compounds. Khimia: Leningrad, 1967, pp. 91-98 (in Russian).

7. Myagkoy, O.N.; Serdiucova, M.I.; Perunova, N.A. Theory and practice of the sorption processes. Voronezh State University: Voronezh, 1980, 15, pp. 73-77 (in Russian).

8. Zelentsov, V.; Datsko, T.Ya. Application of adsorption models in order to describe the equilibrium in the aluminum oxyhydroxide - fluor system. Electronnaya obrabotka materialov, 2012, 48(6), pp. 65-73 (in Russian).

9. Gutsanu, V.; Cojocaru, L.; Lisa, G.; Volodina, G.F. Some metal compounds in the phase of crosslinked ionic polymer- precursors for new sorbents and catalysts. Journal of Applied Polymer Science, 2012, 124, pp. 25822593.

10. Lurie, A.A. Sorbents and Chromatographic Carriers. Nauka: Moscow, 1972, 320 p. (in Russian).

11. Gutsanu, V.; Cojocaru, L. Process for obtaining selective sorbent containing Bi(III) compounds. MD Patent, 2007, No. 3295. (in Romanian).

12. Marcenko, Z. Photometrical Determination of Elements. Mir: Moscow, 1971, 502 p. (in Russian). 